IOSR Journal of Pharmacy

ISSN: 2250-3013, www.iosrphr.org

||| Volume 2 Issue 4 ||| July-August 2012 ||| PP.25-28

\title{
Clinical Study of Heart Disease Complicating Pregnancy
}

\author{
Vidyadhar B Bangal $^{1}$, Rashmi K Singh ${ }^{2}$, Kunaal K Shinde ${ }^{3}$ \\ 1-Professor, 2, 3-Postgraduate students- Department of Obstetrics and Gynecology .Rural Medical College, \\ Loni, Ahmednagar, Maharashtra
}

\begin{abstract}
Heart disease complicating pregnancy is considered as a high risk situation. Increased cardiac demands during the course of pregnancy potentially increase morbidity and mortality in women with underlying heart disease. Risk of adverse outcome is more in rural population as compared to its urban counterpart. A prospective clinical study of 35 cases of pregnancy complicated by heart disease, reporting to tertiary care hospital for delivery, was carried out to find out the incidence and maternal and fetal outcome. The incidence of heart disease in pregnancy in the present study was $1.3 \% \%$.Most of the women (91\%) belonged to low socioeconomic class in the rural population...Rheumatic heart lesions constituted $77 \%$ of the cases. .Mitral stenosis was the commonest lesion in $40 \%$ of cases. Twenty two (62.8\%) women delivered spontaneously vaginally at term and $4(11 \%)$ delivered prematurely. There were 7 ( 20\%) cases of prophylactic forceps delivery. Cesarean section was performed in 2 cases.There was no maternal death.The perinatal mortality was 40 per 1000 live births. Early diagnosis of heart disease, regular antenatal check up , institutional delivery, limiting family size can reduce the maternal and perinatal mortality and morbidity associated with heart disease.
\end{abstract}

Keywords-Heart disease in pregnancy, Rheumatic heart disease, Maternal mortality,

\section{INTRODUCTION}

Hemodynamic changes during normal pregnancy are well tolerated by women with normal cardiac reserve. Diseased heart shows signs of de compensation with resultant increase in morbidity and mortality. It is natural to expect that the fetus would also be compromised in these mothers. Fetal health depends upon an adequate and continuous supply of well-oxygenated maternal blood. In uncompensated heart disease, the oxygen supply becomes limited and that result in compromised fetal growth, there can be growth restriction, premature birth or may even fetal death. Rheumatic heart still remains commonest etiological factor for heart disease complicating pregnancy. It is because of frequent and repeated streptococcal infections in childhood especially in rural areas with poor sanitary conditions .In many pregnant women ,heart disease still remains undiagnosed until complications develop .Even after the diagnosis, many women do not comply with the instructions given by obstetrician for various reasons. Women having additional obstetrical complications further worsen the prognosis. In western countries, maternal heart disease complicates1-3\% of pregnancies and is the third common cause of maternal death during pregnancy.[1-2] Heart disease is one of the 3 major indirect causes of maternal mortality in India .Most data concerning pregnancy course in heart disease patients are anecdotal reports or are in small series ; only a few comprehensive studies are available[4-9] .The primary objective of the present study was to study the incidence of the different cardiac lesions during pregnancy and to assess the effect of heart disease on maternal and fetal health.

\section{MATERIAL AND METHODS}

The present study was carried out over 2 years period at Pravara rural hospital, which is a tertiary care center in Ahmednagar district. All antenatal women diagnosed to be having heart disease were enrolled in the study. Cases were referred to medical specialist for confirmation of cardiac disease and to seek their opinion regarding management. Cases directly reporting to labour room were also included in the study. Detailed history in regard to cardiac lesion was asked. Detailed obstetric history was also gathered to know the effect of cardiac disease on pregnancy and vice versa .Thorough clinical examination was done to find out the type of cardiac lesion, any signs of failure and stage of pregnancy. The case was then investigated with specific investigations to confirm the cardiac lesion and the cardiac functional status. Cases were graded as per NYHA classification of grade of heart disease .Patients were advised to have regular antenatal check up. They were told about the importance of rest, medication and regular visits. In every visit, patients were referred to physician for their opinion regarding cardiac status. Patients were told to have compulsory institutional delivery .Cases reporting during labour were managed as per the cardiac conditions. Patients were kept for 8-10 days after normal delivery and were discharged with advice about contraception, breast feeding and penicillin prophylaxis. 


\subsection{The incidence:}

\section{RESULTS}

The total no of patients admitted for delivery during the study period were 2606.This included 35 cases of heart disease with different lesions. Thus, the incidence of heart disease in pregnancy in the present study was $1.3 \%$.

\subsection{Antenatal registration}

Table. 12 Distribution of cases as per timing of registration

\begin{tabular}{|l|l|l|}
\hline $\begin{array}{l}\text { Trimester of } \\
\text { registration }\end{array}$ & No. of patients & \% \\
\hline First & 2 & 5.7 \\
\hline Second & 6 & 17.1 \\
\hline Third & 14 & 40 \\
\hline Unbooked & 13 & 37.2 \\
\hline
\end{tabular}

It was observed that, out of 35 cases studied, 13 (37\%) were unbooked and 22 ( $63 \%$ ) were booked . The maximum patients were in the age group of 25 to 29 years (40\%) and few were in the age group of 15 to 19 years $(8.5 \%)$. The youngest patient was 18 years old and the oldest patient was of 32 years .

\subsection{Type of heart lesion:}

Table .2 Distributions of cases as per type of lesion

\begin{tabular}{|l|l|l|}
\hline $\begin{array}{l}\text { Type of cardiac } \\
\text { lesion }\end{array}$ & $\begin{array}{l}\text { No. of } \\
\text { cases }\end{array}$ & $\%$ \\
\hline Mitral stenosis (MS) & 14 & 40 \\
\hline $\begin{array}{l}\text { Mitral } \\
\text { Incompetence(MI) }\end{array}$ & 03 & 8.5 \\
\hline MS + MI & 03 & 8.5 \\
\hline MS + PUL. HTN & 06 & 17.5 \\
\hline MS + AR & 02 & 5.7 \\
\hline VSD & 03 & 8.5 \\
\hline ASD & 03 & 8.5 \\
\hline Pulmonary Stenosis & 01 & 2.8 \\
\hline TOTAL & 35 & 100 \\
\hline
\end{tabular}

\subsection{Functional grading (NYHA Classification):}

Table .3.Distribution as per functional grading

\begin{tabular}{|l|l|l|}
\hline Functional & No. of cases & $\%$ \\
\hline GRADE I & 15 & 42.8 \\
\hline GRADE II & 11 & 31.4 \\
\hline GRADE III & 05 & 14.4 \\
\hline GRADE IV & 04 & 11.4 \\
\hline
\end{tabular}

3.5. Cardiac and other complications observed during pregnancy:

Table.4 Distribution of cases as per nature of complications
\begin{tabular}{|l|l|l|l|}
\hline $\begin{array}{l}\text { Cardiac } \\
\text { Complications }\end{array}$ & Antenatal & Intrapartum & $\begin{array}{l}\text { Post } \\
\text { Partum }\end{array}$ \\
\hline $\begin{array}{l}\text { Congestive cardiac } \\
\text { failure }\end{array}$ & 03 & 03 & 01 \\
\hline $\begin{array}{l}\text { Acute pulmonary } \\
\text { edema }\end{array}$ & 02 & 01 & -- \\
\hline $\begin{array}{l}\text { Sub acute bacterial } \\
\text { endocarditis }\end{array}$ & -- & -- & -- \\
\hline Other complications observed during pregnancy \\
\hline $\begin{array}{l}\text { Respiratory tract } \\
\text { infections }\end{array}$ & 05 & -- & -- \\
\hline Anemia & 16 & -- & -- \\
\hline Preterm labour & 08 & -- & -- \\
\hline IUGR & 02 & -- & -- \\
\hline Malaria & 02 & -- & -- \\
\hline
\end{tabular}




\subsection{Mode of delivery:}

Twenty two $(62.8 \%)$ patients delivered spontaneously vaginally at term and $4(11 \%)$ delivered prematurely. There were 7 ( $20 \%$ ) cases of prophylactic forceps delivery. Cesarean section was performed in 2 cases. The average duration of labor was 5 hours in multigravida and 6-8 hours in primigravidae. Injection oxytocin (10 units) was given intramuscularly, after completion of second stage in all cases. One patient had moderate post partum hemorrhage.

\subsection{Birth weight of babies:}

Table. 5 Distribution as per birth weight of babies

\begin{tabular}{|l|l|l|}
\hline $\begin{array}{l}\text { Birth wt in } \\
\text { kgs. }\end{array}$ & Number & \% \\
\hline$<2$ & 06 & 17.3 \\
\hline $2.0-2.4$ & 15 & 42.8 \\
\hline $2.5-2.9$ & 10 & 28.5 \\
\hline$\geq 3.0$ & 04 & 11.4 \\
\hline
\end{tabular}

Incidence of low birth weight was $60 \%$ in heart disease cases as against $42 \%$ in women without heart disease.

\subsection{Details of neonatal deaths:}

Table .6 Details of neonatal deaths

\begin{tabular}{|l|l|l|l|}
\hline $\begin{array}{l}\text { Sr. } \\
\text { No. }\end{array}$ & $\begin{array}{l}\text { Birth } \\
\text { wt } \\
\text { (in } \\
\text { kgs.) }\end{array}$ & $\begin{array}{l}\text { Gestational } \\
\text { age } \\
\text { (in weeks) }\end{array}$ & \multicolumn{1}{|c|}{ Cause of death } \\
\hline 1. & 1.6 & 34 & $\begin{array}{l}\text { Prematurity and respiratory } \\
\text { distress syndrome }\end{array}$ \\
\hline 2. & 1.5 & 35 & $\begin{array}{l}\text { Severe birth asphyxia with } \\
\text { multiple congenital anomalies }\end{array}$ \\
\hline
\end{tabular}

There were only 2 perinatal deaths. One baby died one day after the birth due to prematurity with RDS. The second baby was delivered by assisted breech delivery and died after 2 hrs, due to severe birth asphyxia and multiple congenital anomalies which were incompatible with life.

\section{DISCUSSION}

The number of women with heart disease, who reach childbearing age in a good functional state has increased due to the improved facilities for diagnosis and treatment. As a result, pregnancy becomes a realistic option for many of these young women.There were total 2606 confinements during the year 2001 to 2003, out of which 35 were heart disease cases. Thus, the incidence of heart disease in pregnancy in our study is $1.3 \%$.Most of the patients $(91 \%)$ belonged to low socioeconomic class in the rural population. The commonest age group to which the patient belonged to was 25 to 29 years. The majority of the patients(77\%) were either primigravidae or primipara.In our study, the number of booked cases was higher than the unbooked cases. $63 \%$ were booked and $37 \%$ were unbooked.Rheumatic heart lesions constituted $77 \%$ of the cases. The incidence of RHD is higher, as most of the patients belonged to low socioeconomic class where poverty, poor nutrition, low level of sanitation and hygiene and inaccessibility to health services are common .Mitral stenosis is the commonest heart lesion in $40 \%$ of the lesion.Most patients $(42.8 \%)$ belong to Grade I functional heart disease and $31.4 \%$ of the cases belong to Grade II heart disease. There were 3 cases with a history of mitral valvotomy done 1 year before conception. They were admitted at 35wks and kept under observation. They stood the pregnancy very well and delivered spontaneously at term without any complications. The puerperium was also uneventful.The commonest complaint in the patients was dyspnea on exertion (57\%) followed by palpitation.There were 6 cases of cardiac failure. Cardiac failure occured most commonly between 28 to 36 weeks of gestation. Only one patient developed failure during puerperium .Spontaneous vaginal delivery is the commonest mode of delivery in heart disease cases. 22 patients $(62.8 \%)$ delivered spontaneously per vaginum. Outlet forceps were applied in 7 cases (20\%) only. There was no maternal death . The perinatal mortality was 40 per 1000 live births. Accurate assessment of the individual maternal and foetal risk in pregnant women with heart disease is of fundamental importance for optimal patient care. Despite the diversity and broad morphological and functional variability of heart diseases, few predictors for complications during pregnancy have been recently described. In a prospective multicentre study enrolling 562 women with heart disease monitored in 13 Canadian hospitals, Siu et al. identified poor functional NYHA class or cyanosis, left 
ventricular systolic dysfunction, and left heart obstruction as major determinants for maternal cardiac complications [6]. In the clinical setting, this classification proved to be basically useful and enabled reliable assessment not only of maternal but also of foetal/neonatal risk. Review of the literature indicates that mortality among minimally symptomatic pregnant women with cardiac disease is about $1 \%$ : i.e., within the range of the incidence among the healthy general population $[10,11]$. In contrast, pregnant women with severe symptoms have been reported to experience a mortality risk up to $5-15 \%$ [12].

\section{CONCLUSION}

Heart disease complicating pregnancy is a high risk situation and demands special attention throughout pregnancy. An expert supervision and management by the obstetrician along with physician and the fullest cooperation by the patient throughout antenatal, intranatal and post-natal period, results in achieving the optimum maternal and perinatal outcome. It is essential to educate the rural population about the importance of regular antenatal visits and institutional delivery. Establishing the facilitities for cardiac surgery at affordable cost in rural area will certainly go a long way in decreasing the mortality, morbidity related to heart disease complicating pregnancy.

\section{REFERENCES}

[1]. Arafeh J.M., Baird S.M.Cardiac disease in pregnancy. Crit Care Nurs Q 2006;29:32-52.Medline

[2]. Dobbenga-Rhodes Y.A., Prive A.M.Assessment and evaluation of the woman with cardiac disease during pregnancy. $J$ Perinat Neonatal Nurs 2006;20:295-302.MedlineWeb of Science

[3]. Stangl V., Baumann G., Stangl K.Pregnancy risks in acquired heart diseases. Z Kardiol 2001;90:16-29.CrossRef

[4]. Avila W.S., Rossi E.G., Ramires J.A., et al. Pregnancy in patients with heart disease: experience with 1000 cases. Clin Cardiol 2003;26:135-142 CrossRefMedlineWeb of Science

[5]. Siu S.C., Sermer M., Harrison D.A., et al Risk and predictors for pregnancy-related complications in women with heart disease. Circulation 1997;96:2789-2794.Abstract/FREE Full Text

[6]. Siu S.C., Sermer M., Colman J.M., et al Prospective multicenter study of pregnancy outcomes in women with heart disease. Circulation 2001;104:515-521.Abstract/FREE Full Text

[7]. Siu SC Colman J.M., Sorensen S., et al Adverse neonatal and cardiac outcomes are more common in pregnant women with cardiac disease. Circulation 2002;105:2179-2184.Abstract/FREE Full Text

[8]. Abdel-Hady E.S., El-Shamy M., El-Rifai A.A., et al Maternal and perinatal outcome of pregnancies complicated by cardiac disease. Int J Gynaecol Obstet 2005;90:21-25. CrossRefMedline

[9]. Khairy P., Ouyang D.W., Fernandes S.M., et al Pregnancy outcomes in women with congenital heart disease. Circulation 2006;113:517-524.

[10]. Clark S.L.Cardiac disease in pregnancy. Crit Care Clin 1991;7:777-797. MedlineWeb of Science

[11]. Barbosa P.J., Lopes A.A., Feitosa G.S., et al Prognostic factors of rheumatic mitral stenosis during pregnancy and puerperium. Arq Bras Cardiol 2000;75:215-224. Medline

[12]. Sawhney H., Aggarwal N., Suri V., et al Maternal and perinatal outcome in rheumatic heart disease. Int J Gynaecol Obstet 2003;80:9-14. CrossRefMedline 